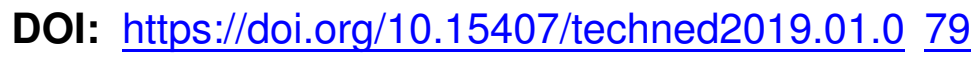

\title{
EXTREME CONTROL SYSTEM FOR PUMP COMPLEX BY THE CRITERION OF MAXIMUM EFFICIENCY
}

Journal

Publisher

ISSN

Issue

Pages
Tekhnichna elektrodynamika

Institute of Electrodynamics National Academy of Science of Ukraine 1607-7970 (print), 2218-1903 (online)

No 1, 2019 (January/February)

$79-84$

\section{Authors}

\section{Zagirnyak, I. Alieksieieva, I. Konoh, T. Korenkova}

Kremenchuk Mykhailo Ostrohradskyi National University, vul. Pershotravneva, 20, Kremenchuk, 39600, Ukraine, e-mail: aljualeks@gmail.com

\begin{abstract}
The criterion of maximum efficiency of extreme automatic control system for pumping complex, which takes into account the requirements of the technological process, specific energy consumption and resource consumption of electrohydraulic equipment, are proposed. The choice of the weight coefficients of the optimality criterion is justified. A structural diagram of the model of an extreme control system for pumping complex of step type with a search algorithm is developed. The energy efficiency of proposed system is analyzed with a pressure stabilization system at the control point of a pipeline network based on a PID controller. The effect of the duration pump operation on the energy characteristics of the pump complex was estimated. Ref erences 10 , figures 5 .
\end{abstract}


Key words: pumping complex, extreme control system, maximum efficiency.

Received: 02.03 .2018

Accepted: 25.06.2018

Published: 10.01 .2019

\section{References}

1. Buryan S.O., Pechenyk M.V., Bodnar D.O. An optimal management the pumping setting is with variation of parameters of hydraulic network. Visnyk NTU KhPI. 2015. No 12 (1121). Pp. 54-59. (Ukr)

2. Kiselychnyk O.I. Investigation of the extreme energy saving neural system of the automatic control of the water supply pump. Visnyk KDPU. 2003. Vyp. 2 (19). Vol. 1. Pp. 78-82. (Ukr)

3. Sotnyk M.I., Boyko V.S., Yurchenko M.M. Determination of the efficiency of operation of electromechanical aggregates. Elektromekhanichni i enerhozberihaiuchi systemy. 2013. Vyp. 2/2013 (22). Vol. 2. Pp. 81-89. (Ukr)

4. Tkachuk O.A., Tkachuk A.O. The main types of changes operating curves of pumping units of water supply pumping stations. Problemy vodopostachannia, vodovidvedennia ta hidravliky. 2006. Vyp 7. Pp. 43-50. (Ukr)

5. Lutsenko I. Identification of target system operations. Development of global efficiency criterion of target operations. Eastern-European Journal of Enterprise Technologies. 2015. Vol. 2. Issue 2 (74). Pp. 35-40. Doi: https://doi.org/10.15587/1729-4061.2015.38963

6. Stavale, Anthony E. (2008). Reducing Reliability Incidents And Improving Meantime Between Repair. Texas A\&M University. Turbomachinery Laboratories. URL: http://hdl.handle .net/1969.1/163924 
7. Zagirnyak M., Korenkova T., Alieksieieva I. Energy and resource saving control system for pumping station. Przeglad Elektrotechniczny. 2013. Vol 2013. No 2b. Pp. 76-80.

8. Zagirnyak M., Kovalchuk V. and Korenkova T. Power Model of an Electrohydraulic Complex with Periodic Nonlinear Processes in the Pipeline Network. Intern. Conf. on Electrical Drives and Power Electronics

(EDPE), Tatranska Lomnica, Slovakia. September 21-23, 2015. Pp. 345-352. DOI: https://doi.org/10.1109/EDPE.2015.7325318

9. Zagirnyak M., Kravets O., Korenkova T. The optimal control of dynamic loads in a pump complex with adjustable pipeline valves. Naukovyi Visnyk Natsionalnoho hirnychoho universytetu . 2016. No 3 (153). Pp. 78-86.

10. Zagirnyak M., Rodkin D. and Korenkova T. Enhancement of instantaneous power method in the problems of estimation of electromechanical complexes power controllability. Przeglad Elektrotechniczny (Electrical review) . 2011. No 12b. Pp. 208-212.

\section{PDF}

